\author{
B. Kenzhegulov ${ }^{1}$, Jaroslav Kultan ${ }^{2}$, D.B. Alibiyev ${ }^{3}$, A.Sh. Kazhikenova ${ }^{3}$ \\ ${ }^{1}$ Kh. Dosmukhamedov Atyrau State University, Atyrau, Kazakhstan; \\ ${ }^{2}$ Ekonomicka univerzita v Bratislave Slovenska republika, Slovensko; \\ ${ }^{3}$ Ye.A. Buketov Karaganda State University, Kazakhstan; \\ (E-mail:aigul-kazhikenova@mail.ru)
}

\title{
Numerical modeling of thermomechanical processes in heat-resistant alloys
}

\begin{abstract}
This article presents a numerical simulation of thermomechanical processes in heat-resistant alloys. The authors develop the law of temperature distribution along the length of the physical body, which is considered as a rod of alloy EI-617. The authors also investigated the dependence of the magnitude of the elongation of the rod from a given temperature. To do this, the rod is conditionally divided into several elements, and then the study is carried out in one area. To determine the temperature dependence, the temperature distribution field is approximated by a full polynomial of the second degree, and approximation spline functions are introduced. Using a temperature gradient for one element, the functional expression characterizing the total thermal energy is written, first for the $(n-1)$ element, then for the last $n$-th element. The total thermal energy is expressed by the formula $J=\sum_{i=1}^{n} J_{i}$. By minimizing the total thermal energy, we obtain a system of algebraic equations for determining the nodal values of temperatures. Applying the obtained values, the elongation of the element due to thermal expansion is calculated. The relationship between the temperature $T$, elongation $\Delta l_{T}$, «tensile» force $R$, and «tensile stress» $\sigma$. is shown in the work. It is shown that with increasing temperature, the above values proportionally increase.
\end{abstract}

Keywords: thermal expansion, modulus of elasticity, rod, elongation, thermal stress state, sampling.

\section{Introduction}

Intensive development of modern technological processes in the field of metal science creates favorable conditions for the production of more advanced heat-resistant alloys with high resistance to plastic deformation and destruction under the influence of high temperatures.

This article presents the experimental temperature dependences of the coefficient of thermal expansion and the elastic modulus of the alloy EI-617, which are determined experimentally. Taking into account the experimental dependence of the modulus of elasticity and the coefficient of thermal expansion of the alloy material on temperature, the problem of determining the field of temperature distribution, elongation, and thermal stress state of a rod of limited length made of EI-617 alloy is considered.

The coefficient of thermal expansion $\alpha\left(\frac{1}{{ }^{\circ} \mathrm{C}}\right)$ of this alloy is strictly dependent on temperature. In [1,2] values are given at various temperatures. Studying experimental materials received the corresponding functional dependence

1) for $20^{\circ} \mathrm{C} \leq T \leq 100^{\circ} \mathrm{C}, \alpha=0,0225 \cdot 10^{-6} \times T+9,65 \cdot 10^{-6}\left(\frac{1}{{ }^{\circ} \mathrm{C}}\right)$

2) for $100^{\circ} C \leq T \leq 200^{\circ} C, \alpha=0,013 \cdot 10^{-6} \times T+10,6 \cdot 10^{-6}\left(\frac{1}{{ }^{\circ} C}\right)$

3) for $200^{\circ} \mathrm{C} \leq T \leq 300^{\circ} \mathrm{C}, \alpha=0,015 \cdot 10^{-6} \times T+10,2 \cdot 10^{-6}\left(\frac{1}{{ }^{\circ} \mathrm{C}}\right)$

4) for $300^{\circ} \mathrm{C} \leq T \leq 400^{\circ} \mathrm{C}, \alpha=0,023 \cdot 10^{-6} \times T+7,8 \cdot 10^{-6}\left(\frac{1}{{ }^{\circ} \mathrm{C}}\right)$

5) for $400^{\circ} C \leq T \leq 500^{\circ} C, \alpha=0,013 \cdot 10^{-6} \times T+11,6 \cdot 10^{-6}\left(\frac{1}{{ }^{\circ} C}\right)$ 
6) for $500^{\circ} \mathrm{C} \leq T \leq 600^{\circ} \mathrm{C}, \alpha=0,02 \cdot 10^{-6} \times T+8,3 \cdot 10^{-6}\left(\frac{1}{{ }^{\circ} \mathrm{C}}\right)$

7) for $600^{\circ} \mathrm{C} \leq T \leq 700^{\circ} \mathrm{C}, \alpha=0,017 \cdot 10^{-6} \times T+10,1 \cdot 10^{-6}\left(\frac{1}{{ }^{\circ} \mathrm{C}}\right)$

8) for $700^{\circ} \mathrm{C} \leq T \leq 800^{\circ} \mathrm{C}, \alpha=0,012 \cdot 10^{-6} \times T+13,6 \cdot 10^{-6}\left(\frac{1}{{ }^{\circ} \mathrm{C}}\right)$

\section{Experimental}

Let's consider a horizontal cylinder-shaped body (hereinafter referred to as the rod) of limited length and made of heat-resistant alloy EI-617.

The thermal conductivity of the rod material is denoted by $K_{x x}\left(\frac{W}{m c \cdot{ }^{\circ} C}\right)$. The coefficient of thermal expansion of the rod material is denoted by $\alpha=\alpha(T(x))\left(\frac{1}{{ }^{\circ} \mathrm{C}}\right)$. The length of the rod is denoted by $L(\mathrm{~cm})$, and the cross-sectional area is denoted by $F\left(\mathrm{~cm}^{2}\right)$. We consider the left end of the body (rod) under consideration to be rigidly pinched, and the free end to the right. An axial tensile force $P(k G)$ is applied at the free end. We will direct the axis $O x$ from left to right. It coincides with the axis of the rod. Throughout the length of the rod, the area of the lateral surface, as well as through the cross-sectional area of the right end of the rod, is exchanged with the environment. In this case, the heat transfer coefficient is $h\left(\frac{W}{m c \cdot{ }^{\circ} C}\right)$, and the ambient temperature is $T_{a t}\left({ }^{\circ} \mathrm{C}\right)$. At the left pinched end of the rod, a constant temperature $T(x=0)=T_{1}$ is set $[3,4]$. The calculation scheme of the problem under consideration is given in Figure 1.

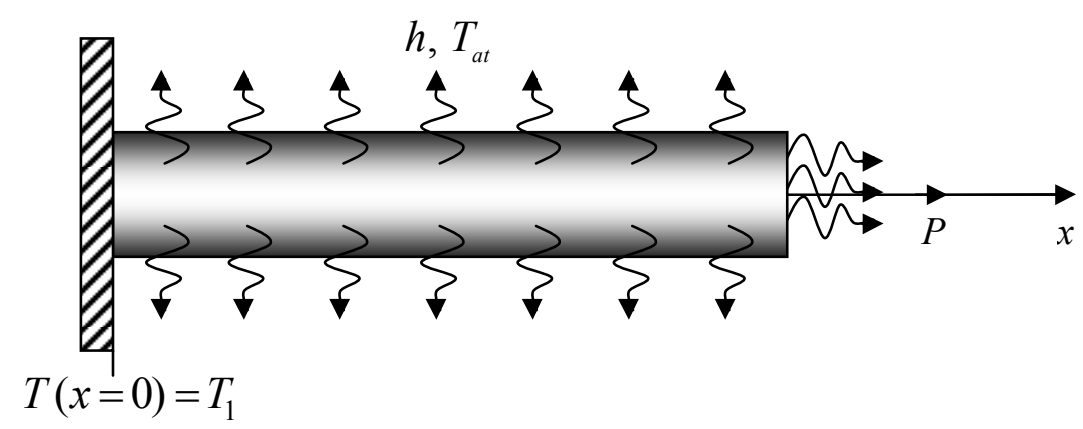

Figure 1. The calculation scheme of the problem.

The purpose of this article is to determine the law of the temperature distribution along the length of the rod under study, as well as the dependence of the rod elongation on the value of the given temperature $T(x=0)=T_{1}$. Here it is necessary to take into account the experimental dependence of the coefficient of thermal expansion of the material of the rod on temperature. To do this, we first discretize the test rod into $n$ elements of the same length $l=\frac{L}{n}(\mathrm{~cm})$. For example, consider one discrete element. Within each local element, the temperature distribution field is approximated by a second-order full polynomial, i.e.

$$
T(x)=a x^{2}+b x+c, 0 \leq x \leq l, a, b, c-\text { const. }
$$

If within one local element accept that

$$
T_{i}=T(x=0) ; T_{j}=T\left(x=\frac{l}{2}\right) ; T_{k}=T(x=l)
$$

then within this element we can rewrite (1) in the following form 


$$
T(x)=\varphi_{i}(x) \cdot T_{i}+\varphi_{j}(x) \cdot T_{j}+\varphi_{k}(x) \cdot T_{k}, 0 \leq x \leq l,
$$

where $\varphi_{i}(x), \varphi_{j}(x)$ and $\varphi_{k}(x)$ are approximate spline functions which are called form functions for a quadratic discrete element with three nodes. They have the following form:

$$
\varphi_{i}(x)=\frac{l^{2}-3 l x+2 x^{2}}{l^{2}} ; \varphi_{j}(x)=\frac{4 l x-4 x^{2}}{l^{2}} ; \varphi_{k}(x)=\frac{2 x^{2}-l x}{l^{2}} ; 0 \leq x \leq l
$$

Within one element, the temperature gradient is determined as follows:

$$
\frac{\partial T}{\partial x}=\frac{\partial \varphi_{i}(x)}{\partial x} T_{i}+\frac{\partial \varphi_{j}(x)}{\partial x} T_{j}+\frac{\partial \varphi_{k}(x)}{\partial x} T_{k}, 0 \leq x \leq l
$$

For $(n-1)$ elements we can write an expression of the functional that characterizes its total thermal energy:

$$
J_{i}=\int_{V_{i}} \frac{K_{x x}}{2}\left(\frac{\partial T}{\partial x}\right)^{2} d V+\int_{S_{I S i}} \frac{h}{2}\left(T-T_{a r}\right)^{2} d S
$$

where $i=1 \div(n-1) ; V_{i}$ is the volume of the $i$-th discrete element; $S_{I S i}$ is the area of the lateral surface of the $i$-th element.

Now we can write an expression of a similar functional for the last $n$-th discrete element:

$$
J_{n}=\int_{V n} \frac{K_{x x}}{2}\left(\frac{\partial T}{\partial x}\right)^{2} d V+\int_{S_{I S i}} \frac{h}{2}\left(T-T_{a t}\right)^{2} d S+\int_{S_{x=L}} \frac{h}{2}\left(T-T_{a t}\right)^{2} d S
$$

where $S(x=L)$ is the cross-sectional area of the right end of the investigated body through which heat exchange also takes place with the environment. Then for the investigated body as a whole, the expression of the functional that characterizes its total thermal energy has the following form:

$$
J=\sum_{i=1}^{n} J_{i}
$$

Now, minimizing $J$ by the nodal temperature values, we obtain a resolving system of linear algebraic equations:

$$
\frac{\partial J}{\partial T_{i}}=0, i=2 \div(2 n+1)
$$

Here $i$ changes from 2, because it is considered that $T_{1}=T(x=0)$ is given.

\section{Results and Discussion}

Using the Gauss method, solving system (9) determines the nodal temperature values. According to them, for each local discrete element, the following integral is calculated, the essence of which is the extension of the element due to thermal expansion:

$$
\Delta l_{i}=\int_{0}^{l}\left[\varphi_{i}(x) \cdot \alpha_{i}+\varphi_{j}(x) \cdot \alpha_{j}+\varphi_{k}(x) \cdot \alpha_{k} \llbracket\left[\varphi_{i}(x) \cdot T_{i}+\varphi_{j}(x) \cdot T_{j}+\varphi_{k}(x) \cdot T_{k}\right] d x \quad 0 \leq x \leq l\right.
$$

Then the total elongation of the test body is determined by the following formula:

$$
\Delta l=\sum_{i=1}^{n} \Delta l_{i}
$$

It should be noted that for different values of the given temperature $T_{1}=T(x=0)$, the corresponding value of $\Delta l$ is obtained.

For the purposes of a numerical study of dependencies of $\Delta l=\Delta l\left(T(x=0)=T_{1}\right)$, we take the following for initial data:

$$
\begin{gathered}
K_{x x}=72 \mathrm{~W} /\left(\mathrm{cm} \cdot{ }^{\circ} \mathrm{C}\right) ; h=10 \mathrm{~W} /\left(\mathrm{cm}^{2} \cdot{ }^{\circ} \mathrm{C}\right) ; T_{a t}=40 C ; T(x=0)=T_{1}=(100 \div 800)^{\circ} \mathrm{C} ; \\
L=30 \mathrm{~cm} ; n=300 ; l=\frac{L}{n}=0,1 \mathrm{~cm} ; r=1 \mathrm{~cm} ; \quad F=\pi r^{2}=\pi ; P=2 \pi r=2 \pi .
\end{gathered}
$$

The corresponding field of temperature distribution along the length of the rod with such initial data is shown in Figure 2. 


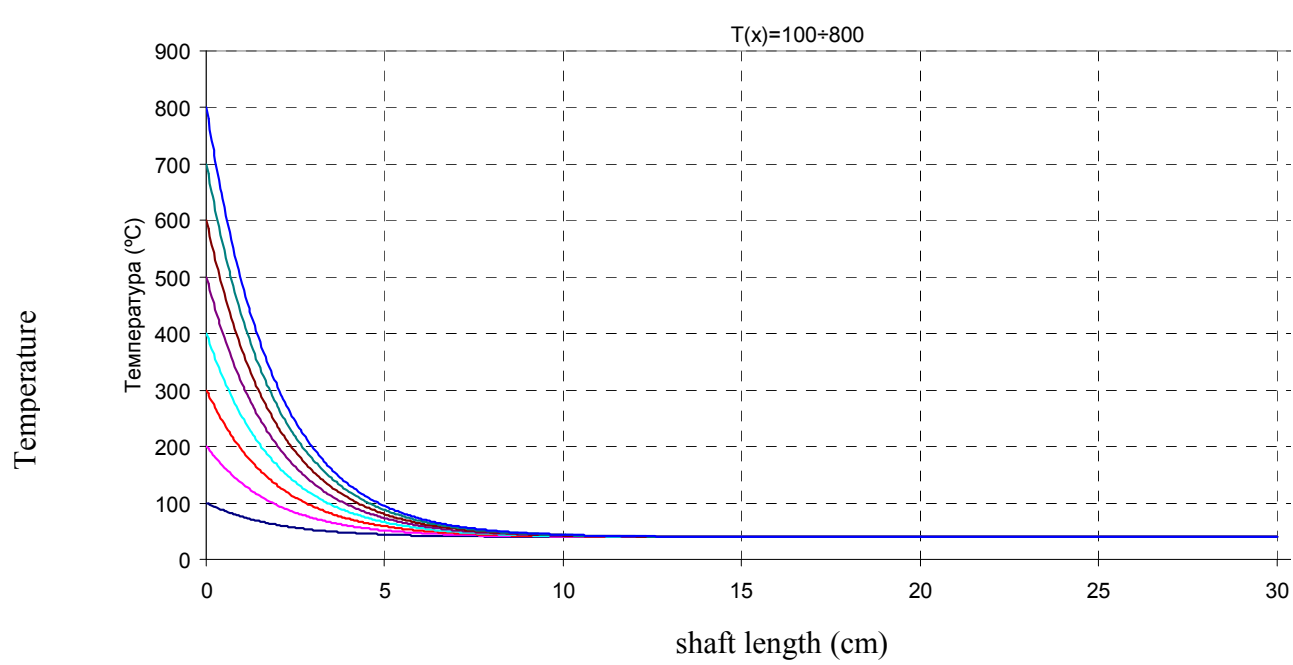

Figure 2. Dependence of $T=T(x)$ on $T_{1}$

Dependence between $T_{1}$ and $\Delta l_{T}, R, \sigma$

\begin{tabular}{|c|c|c|c|c|c|c|c|}
\hline № & $T_{1}\left({ }^{\circ} \mathrm{C}\right)$ & $\Delta l_{T}(\mathrm{~cm})$ & $\begin{array}{c}\text { Equivalent «tensile» force } \\
R(k G) \text { at which such an } \\
\text { elongation would result }\end{array}$ & $\begin{array}{c}\text { Equivalent } \\
\text { «tensile stress» } \\
\sigma\left(\mathrm{kG} / \mathrm{cm}^{2}\right)\end{array}$ & $\begin{array}{c}\overline{\Delta l_{T}}(\mathrm{~cm}) \text { at } \\
\alpha=\mathrm{const} \\
10,1 \cdot 10^{-6}\left(1 /{ }^{\circ} \mathrm{C}\right)\end{array}$ & $\begin{array}{c}\text { Elongation } \\
\text { in\% }\end{array}$ & $k=\frac{\Delta l_{T}}{\overline{\Delta l_{T}}}$ \\
$($ times $)$
\end{tabular}

Figure 2 shows the temperature distribution field along the length of the rod at different values of $T_{1}$, and Table 1 shows the values of $\Delta l_{T}$ at different values of $T_{1}$, i.e. dependence between $T_{1}$ and $\Delta l_{T}, R, \sigma$. Figure 2 shows that the temperature distribution field along the length of the rod will be a smooth curve. A graphic relationship between the values of the temperature source $\left(T_{1}\right)$ and the corresponding elongation $\left(\Delta l_{T}\right)$ of the rod from thermal expansion is shown in Figure 3.

When $T_{1}=100\left({ }^{\circ} \mathrm{C}\right)$, starting with $x=15,5(\mathrm{~cm})$, i.e. at the site $15,5 \leq x \leq 30(\mathrm{~cm})$ there is a constant temperature, the value of which is equal to $\approx 40\left({ }^{\circ} C\right)$. In this case, due to thermal expansion, the body (rod) is extended by $\Delta l_{T}=0,014(\mathrm{~cm})$. For comparison, it can be noted that this extension is equivalent to the extension of the rod, if it is stretched by force $R=2930,66(k G)$. Naturally, on the basis of Hooke's law in this case a tensile stress of magnitude $\sigma=933,33\left(\mathrm{kG} / \mathrm{cm}^{2}\right)$ would arise in the cross section of the rod.

When $T_{1}=200\left({ }^{\circ} \mathrm{C}\right)$, i.e. with an increase in the set temperature by a factor of two, a $40\left({ }^{\circ} \mathrm{C}\right)$ temperature field is observed in the area $19,2 \leq x \leq 30(\mathrm{~cm})$. In this case, the elongation of the body (rod) is $\Delta l_{T}=0,0165(\mathrm{~cm})$ and will be $17.657 \%$ greater than in the case $T_{1}=100\left({ }^{\circ} \mathrm{C}\right)$. This magnitude of elongation 
is equivalent to elongation of the rod under tensile load $R=3454(k G)$. In this case, tensile stress would be $\sigma=1100\left(\mathrm{kG} / \mathrm{cm}^{2}\right)$.

When $T_{1}=300\left({ }^{\circ} \mathrm{C}\right)$, i.e. when to increase the value of the point temperature by three times the value $\Delta l_{T}=0,0193(\mathrm{~cm})$, which exceeds by $37.857 \%$ than in the case $T_{1}=100\left({ }^{\circ} \mathrm{C}\right)$. It should also be noted that in this case, at the site $21,1 \leq x \leq 30(\mathrm{~cm})$ of the body (rod), a constant temperature is observed close to the ambient temperature of the body (rod). In this case, the value $\Delta l_{T}$ is equivalent to stretching the considered rod with force $R=4040,1(k G)$. In this case, the tensile stress arising in the cross sections would be $\sigma=1286,66\left(\mathrm{kG} / \mathrm{cm}^{2}\right)$. It should be noted that for ordinary steels this voltage already exceeds the proportional limit.

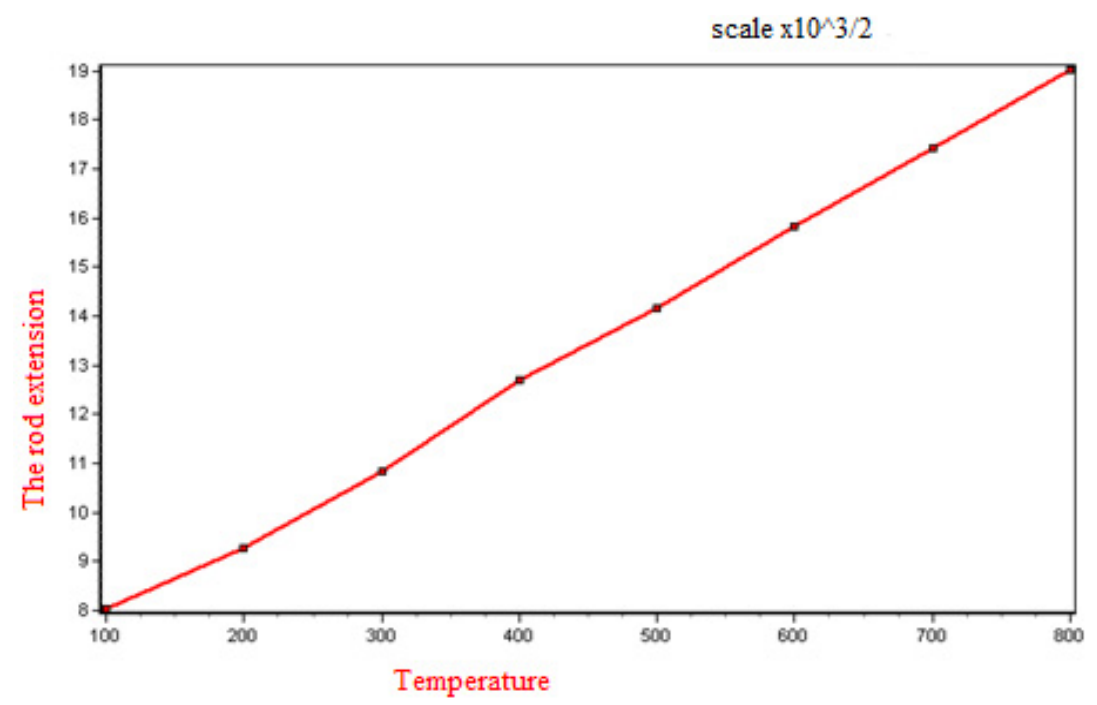

Figure 3 - Graphic relationship between $T_{1}$ and $\Delta l_{T}$

When $T_{1}=400\left({ }^{\circ} \mathrm{C}\right)$, i.e. Now increasing the value $T_{1}$ four times, we have that $\Delta l_{T}=0,02247(\mathrm{~cm})$. This is equivalent to the elongation of the rod when it is stretched by a force whose magnitude is $R=4703,72(k G)$. In this case, a tensile stress of magnitude $\sigma=1498\left(\mathrm{kG} / \mathrm{cm}^{2}\right)$ would arise in the cross sections of the rod. Naturally for ordinary steels, this stress is considered destructive.

When $T_{1}=500\left({ }^{\circ} \mathrm{C}\right)$, value $\Delta l_{T}=0,02595(\mathrm{~cm})$. This is $85 \%$ more than the same value $\Delta l_{T}$ at $T_{1}=100\left({ }^{\circ} \mathrm{C}\right)$. It should be noted here that in order to obtain an elongation of the rod in size $\Delta l_{T}=0,02595(\mathrm{~cm})$ when it is stretched, it would be necessary to stretch with force $R=5432,2(\mathrm{kG})$. At the same time, tensile stress $\sigma=1730\left(\mathrm{kG} / \mathrm{cm}^{2}\right)$ would appear in the cross sections of the rod, which is large for ordinary steel structures.

With $T_{1}=600\left({ }^{\circ} \mathrm{C}\right)$, the value $\Delta l_{T}=0,0297(\mathrm{~cm})$ and it will be $112.14 \%$ more than $\Delta l_{T}$ at $T_{1}=100\left({ }^{\circ} \mathrm{C}\right)$ . Equivalent tensile force would be equal to $R=6217,2(k G)$ and the corresponding tensile stress would be equal to $\sigma=1980\left(\mathrm{kG} / \mathrm{cm}^{2}\right)$. Comparing the results obtained, it is interesting to note that when the temperature value $T_{1}$ increases from $T_{1}=100\left({ }^{\circ} \mathrm{C}\right)$ to $T_{1}=600\left({ }^{\circ} \mathrm{C}\right)$, the values of $\Delta l_{T}, R, \sigma$ increase equally by $112.14 \%$.

\section{References}

1 Ноздрев В.Ф. Курс термодинамики / В.Ф. Ноздрев. - М.: Просвещение, 1967. — 248 с.

2 Сегерлинд Л. Применение метода конечных элементов / Л. Сегерлинд. - М.: Мир, 1979. - 392 с. 
3 Kenzhegulov B. Numerical solution of problem of thermo elasticity with provision for dependencies between the factor of heat expansion and temperature / B. Kenzhegulov // International journal of scientific articles. Science and technology - 2009. - 5. - P. 3-7.

4 Kenzhegulov B. Numeral modeling of heat mechanical condition of core of limited lengths made of heat resistant alloy ANV -300 at presence of heat exchange, partial heat insulation, local temperature and axial spraining power / B. Kenzhegulov // International journal of scientific articles. Science and technology - 2009. - 5. - P. 8-14.

\title{
Б. Кенжегулов, Я. Култан, Д.Б. Алибиев, А.Ш. Кажикенова \\ Қызуға төзімді құйманың жылумеханикалық процестерін сандық модельдеу
}

\begin{abstract}
Мақалада қызуға төзімді құйманың жылумеханикалық процестерін сандық модельдеу келтірілген. ЭИ-617 құймасынан жасалған сырықты негізге ала отырып, авторлар физикалық дененің ұзына бойы жылу таралу заңдылығы қарастырылған. Берілген жылуға сырықтың ұзару шамасының тәуелділігі зерттелген. Бұл үшін сырық шартты түрде бірнеше элементтерге бөлінеді, соның бір бөлігіне зерттеу жүргізілген. Жылу таралу өрісінің жылуға тәуелділігін анықтау үшін екінші ретті толық полиноммен аппроксимация жасаймыз және аппроксимациялық сплайн функция енгіземіз. Алдымен $(n-1)$ элемент, сосын соңғы $n$ элемент үшін толық жылу энергиясын өрнектейтін, жылу градиентінің көмегімен бір элемент үшін функционал өрнегі жазылады. Толық жылу энергиясы $J=\sum_{i=1}^{n} J_{i}$ формуласымен өрнектеледі. Толық жылу энергиясын минимизациялау арқылы түйінді нүктедегі жылудың мәнін анықтау үшін алгебралық теңдеулер жүйесін аламыз. Алынған мәндер арқылы, жылу ұлғаюдың есебінен элементтің ұзаруы есептеледі. Жұмыста $T$ жылу, $\Delta l_{T}$ ұзару, $R($ кГ) «созылу» күші, $\sigma$ «созылу» кернеуінің өзара тәуелділігі келтірілген. Жылудың өсу есебінен аталған шамалардың пропорционалды өсетіндігі көрсетілген.
\end{abstract}

Кілm сөздер: жылудан ұлғаю, серпімділік модулі, сырық, сырықтың ұзаруы, жылукернеулік күйі, дискреттеу.

\section{Б. Кенжегулов, Я. Култан, Д.Б. Алибиев, А.Ш. Кажикенова \\ Численное моделирование термомеханических процессов в жаропрочных сплавах}

\begin{abstract}
В статье приведено численное моделирование термических процессов в жаропрочных сплавах. Авторами разработан закон распределения температуры по длине физического тела, в качестве которого рассматривают стержень из сплава ЭИ-617. Кроме того, исследована зависимость величины удлинения стержня от заданной температуры. Для этого стержень условно поделен на несколько элементов, а затем исследование проводится на одном участке. Для определения температурной зависимости поле распределения температур аппроксимируется полным полиномом второй степени, а также вводятся аппроксимационные сплайн-функции. С помощью градиента температуры для одного элемента записывается выражение функционала, характеризующее полную тепловую энергию, сначала для (n-1)-го элемента, затем для последнего $n$-го элемента. Полная тепловая энергия выражена формулой $J=\sum_{i=1}^{n} J_{i}$. Минимизируя полную тепловую энергию, получаем систему алгебраических уравнений для определения узловых значений температур. Применяя полученные значения, вычисляется удлинение элемента за счет теплового расширения. В работе приведена зависимость между температурой $T$, удлинением $\Delta l_{T}$, «растягивающей» силой $R(\kappa \Gamma)$ и «растягивающим напряжением» $\sigma$. Показано, что с повышением температуры пропорционально увеличиваются и названные величины.
\end{abstract}

Ключевые слова: тепловое расширение, модуль упругости, стержень, удлинение, термонапряженное состояние, дискретизация.

\section{References}

1 Nozdrev, V.F. (1967). Kurs termodinamiki [The course of thermodynamics]. Moscow: Prosveshchenie [in Russian].

2 Segerlind, L. (1979). Primenenie metoda konechnykh elementov [Applied Finite Element Analysis]. Moscow: Mir [in Russian].

3 Kenzhegulov, B. (2009). Numerical solution of problem of thermo elasticity with provision for dependencies between the factor of heat expansion and temperature. International journal of scientific articles. Science and technology, 5, 3-7. 
4 Kenzhegulov, B. (2009). Numeral modeling of heat mechanical condition of core of limited lengths made of heat resistant alloy ANV -300 at presence of heat exchange, partial heat insulation, local temperature and axial spraining power. International journal of scientific articles. Science and technology, 5, 8-14. 